\title{
Marketing Manufacturer and Retailer House Brands: A Study of Shelf Space in Two Product Categories
}

\author{
Ranga Chimhundu ${ }^{1}$ \\ ${ }^{1}$ School of Management and Marketing, Faculty of Business and Law, University of Southern Queensland, \\ Toowoomba, Australia \\ Correspondence: Ranga Chimhundu, School of Management and Marketing, Faculty of Business and Law, \\ University of Southern Queensland, Toowoomba, QLD 4350, Australia. Tel: 61-7-4687-5759. E-mail: \\ Ranga.Chimhundu@usq.edu.au
}

Received: September 1, 2012 Accepted: September 26, 2012 Online Published: November 2, 2012

doi:10.5539/ijms.v4n6p35 URL: http://dx.doi.org/10.5539/ijms.v4n6p35

\begin{abstract}
This article investigates shelf space allocation in the marketing of manufacturer brands (national brands) and retailer house brands (store brands) in the consumer packaged goods sector in a highly concentrated grocery retail environment. Of special interest is the degree to which the market mechanism is still at play in this kind of environment where retail chains wield considerable power over manufacturers supplying the respective grocery retail categories. The study focuses on two consumer packaged goods categories, and data collection is conducted via a combination of in-store category observation and in-depth interviews. The results of in-store category observation data indicate that the shelf space occupied by retailer house brands is largely proportional to the market share of the retailer house brands, which tends to negate the possibility of abuse of power within the product categories studied. Analysis of research interview data unveiled a number of themes that seem to collectively indicate that, both the manufacturer brand and the retailer house brand will continue to have a home in the respective categories, and performance on the part of manufacturer brands is expected for them to be able to justify occupation of valuable shelf space ahead of other competing manufacturer brands in the tightly contested shelf arena. The study points to the importance of participation of both manufacturer and retailer house brands if optimum category performance is to be achieved.
\end{abstract}

Keywords: manufacturer brand, retailer house brand, private label, shelf space, product category, consumer goods

\section{Introduction}

The sharing of shelf space between manufacturer brands (national brands) and retailer house brands (store brands) is an integral part of the coexistence of these two types of brands in consumer packaged goods categories in all grocery retail industries around the world where retailer house brands are now in existence. The subject of shelf space between these brands is important because the two types of brands are simultaneously in some form of competition and cooperation. How this complicated situation affects the way in which shelf space is allocated becomes an important subject to study especially given the fact that studies by researchers such as Frank and Massy (1970) and Suarez (2005) among others, have shown that greater shelf space is desirable for any brand as there is a positive relationship between the shelf space allocated to a brand and the sales performance of the brand. Previous studies on possible preferential treatment of the retailer house brand in the allocation of shelf space have produced conflicting results (e.g. Bell \& Duder, 1998; Gomez \& Rubio's, 2008), and this would lead one to believe that there is no standard practice with respect to how shelf space allocation is treated. Systemmatic approaches such as category management may exist and may be practised in a number of consumer packaged goods industries, but these may not really tell the whole story, especially in highly concentrated grocery retail environments where retail chains wield considerable power over manufacturers. This research therefore is an intensive study of the subject of shelf space allocation between retailer house brands and manufacturer brands in a grocery retail environment that has a high retail concentration level, and has the objective of eastablishing the extent to which dependency relationships between the two types of brands have a bearing on shelf space decisions. The article is organised as follows: - firstly, a theoretical background section discusses the literature on dependency and shelf space, and ends up outlining the objectives of the study. This is followed by a description 
of the methodology employed, and finally by a separate section on the results and discussion of the study.

\section{Theoretical Background}

\subsection{Dependency}

Dependency is the state of one party relying on another for economic, social or other benefits, and dependency theory argues that the power to influence or control rests in the extent to which one party depends on the other for the things that they value (Emerson, 1962; Hickson, Hinings, Less, Schneck \& Pennings, 1971; Pfeffer, 1981). Relationships normally mean mutual dependence between relevant parties (Emerson, 1962; Hickson et al., 1971). While the academic literature largely treats dependency theory from the view-point of humans and organisations, it is appropriate to extend the application of this theory to the coexistence of entities such as brands. Putting the coexistence relationship of manufacturer brands and retailer house brands, and the respective relationship between the relevant manufacturers and retailers in the context of dependency theory would make sense if there is an element of one of the two types of brands (and the respective owners of the brands) depending on the other, or both types of brands depending on each other. Specifically, how this dependency may have an influence in the way scarce resources such as shelf space are shared between manufacturer and retailer brands in the product categories of consumer packaged goods retail outlets is a subject that warrants investigation, especially from the view-point that even if the two types of brands are in some sort of competition, there is a considerable degree of cooperation as well between them.

Dependency has been conceptualised from the perspective of types of interdependence. Thompson (1967) identified pooled, sequential and reciprocal interdependence as three forms of interdependence. Although these were conceptualised as types of internal organisational interdependence, they can be applied to manufacturer and retailer category relationships, and effectively to manufacturer brand and retailer house brand coexistence relationships on the shelves. Pooled interdependence is a situation in which each unit "renders a discrete contribution to the whole and each is supported by the whole" (Thompson, 1967, p. 54). If each party does not perform adequately, the performance of the whole is negatively affected. Sequential interdependence takes a serial form, with the output of one unit acting as input of another; and reciprocal interdependence involves give and take. With respect to grocery retail categories, it is reasonable to suggest that if there is an element of category participants bringing something to the categories that the other participant(s) would in turn draw from, then there is pooled interdependence, even if it is just two parties involved. This research on manufacturer brands and retailer house brands seeks to take a closer look at these issues as they relate to the subject of shelf space between manufacturer and retailer house brands.

Important to note also, according to Ogbonna and Wilkinson (1998) is the fact that relationships such as manufacturer - retailer relationships do not exist in a vacuum, but in a wider political and social context that regulates that relationship. In this regard it is reasonable to suggest that industry contexts would be relevant when it comes to how shelf space between the two types of brands is treated. Manufacturer-retailer relationships and the respective handling of shelf space issues in a marketing environment characterised by high retail concentration would be expected to be different from relationships set in a low retail concentration environment. However, despite the fact that it is widely recognised in the literature that power in the FMCG sector has largely shifted from manufacturers to retailers because of factors such as increased retail consolidation and concentration, the growth of retailer house brands, and the increased utilisation of information technology by retailers (e.g. Hogarth-Scott, 1999; Nielsen, 1992), the seemingly simultaneous competitive and cooperative nature of the relationship between manufacturer and retailer house brands makes it reasonable to suggest that dependency/interdependence involving the two types of brands has an important role to play on shelf matters.

\subsection{Literature on Shelf Space}

A number of studies have explored the subject of shelf space in the marketing of consumer packaged goods from a variety of perspectives (e.g. Amrouche \& Zaccour, 2006; Bell \& Duder, 1998; Dreze, Hoch \& Purk, 1994; Frank \& Massy, 1970; Gomez \& Rubio, 2008; Sethuraman, 2006; Suarez, 2005). The list is by no means exhaustive as it is not meant to be. Some of these studies have shown a positive relationship between the size of shelf space occupied by a brand and the sales and/or market share performance of the respective brand (e.g. Frank \& Massy, 1970; Suarez, 2005). The higher the shelf space, the higher the sales level and the respective market share. In this regard, shelf space is a desirable input performance measure.

By implication, in the competition between manufacturer and retailer house brands, if retail chains would choose to use their muscle to tilt merchandising measures in favour of their retailer house brands, this would be expected to act in the retailer house brands' favour from a sales and market share perspective. Such a scenario is possible, especially given the perception that house brands are guaranteed good shelf space and full distribution by the 
retail chains who indeed own the retail shelves (Hoch, 1996; Suarez, 2005), and the observation that retailer house brands have overall control of the market in which the two types of brands operate (Hultman, Opoku, Salehi-Sangari, Oghazi \& Bui, 2008). In the category management set-up, this creates the likelihood that retailer house brands could actually be exempt from the normal category management rules and therefore opening the way for them to receive favourable treatment if need be. Given this possible sacred cow status for retailer house brands, and the competition between retailer house brands and manufacturer brands, as well as the balance of power that is in favour of retailers in the retailer-manufacturer relationship, it is expected that retailers would be giving their retailer house brands more shelf space than they probably deserve. In addition, the fact that retailer house brands tend to generally offer higher profit margins (for the retailers) than manufacturer brands due to their lower cost structure would act as further justification for the retail chains to want to give retailer house brands favourable treatment on shelf matters.

Studies have been carried out on topics related to this particular issue (e.g. Bell \& Duder, 1998; Gomez \& Rubio, 2008) and these studies have produced conflicting results. Bell and Duder (1998) studied three product categories in 50 supermarket stores and found that grocery retailers were not favouring their retailer house brands with respect to shelf facings and better position on the shelves. Conversely, a much later study by Gomez and Rubio (2008) employed the survey method and found that "on average, manufacturers consider that retailers are favouring unequal competition terms between manufacturer and store brands" (p. 50). Also currently, anecdotal evidence has supported this latest research result. The conflict in these studies could be explained by the fact that, as far back as 1996, the year the data for Bell and Duder (1998) was collected in New Zealand, grocery retail consolidation and concentration in the country had not reached the level it is today, and the emphasis on retailer brand development and category management had not intensified to the level it is currently. Therefore the latest situation would be expected to be consistent with Gomez and Rubio's (2008) study although the study was carried out in a different environment; Spain, which actually has a lower grocery retail concentration level than New Zealand. Or the explanation may simply be attributed to differences in retailer brand strategies by the respective retail chains involved in the different FMCG industries. Even then, one would still reason that retailer brand strategies that were suitable more than a decade ago, for instance in the case of the results of the study by Bell and Duder (1998), may not really be justifiable in a radically-altered FMCG landscape (Kumar \& Steenkamp, 2007) characterised by increased retailer power and direct competition between brands owned and managed by owners of the retail shelves (retailer house brands) and those owned and managed by manufacturers (manufacturer brands). These issues therefore justify an intensive investigation of the shelf space situation in this new environment. A focused, intensive study of a specific FMCG/supermarket industry would yield valuable insights into how the shelf space issue is handled, and why; especially with respect to dependency relationships between the two types of brands.

\subsection{Objectives of the Study}

The research aims to assess the extent to which the shelf space situation between manufacturer brands and retailer house brands in consumer packaged goods categories in an environment of high grocery retail concentration reflects dependency relationships between the two types of brands. In this regard, the study seeks to specifically establish shelf space in selected categories for the two types of brands, and then assess the extent to which dependency relationships between the two types of brands have a bearing on the shelf space situation.

\section{Methodology}

The research made use of a combination of quantitative and qualitative data. Since the investigation was on how the shelf space situation between manufacturer and retailer house brands in supermarket product categories stands, and why; this called for a method that enabled the exploration of observable phenomena (Guba \& Lincoln, 1994) such as the respective shelf space (and facings) of the brands, and the exploration of non-observable phenomena (Guba \& Lincoln, 1994) such as the underlying causal tendencies. In this regard, the research employed the case study methodology (Yin, 2003) which was chosen for its ability to address the what, how and why questions of shelf space for the two types of brands, and its ability to cater for the need to "gain a deep understanding" (Perry, Riege \& Brown, 1999, p. 20) of managerial decisions relating to shelf space for manufacturer and retailer house brands in the categories. Furthermore, case study research can rely on various sources of evidence, allowing data to converge via triangulation (Yin, 2003). Thus the convergence of quantitative and qualitative data on the research issues in question was seen as an important aspect in enhancing the quality of this investigation.

The research was conducted in the New Zealand FMCG sector, which was considered to be suitable for the purpose of the research as it has a high level of grocery retail concentration. The study focused on two categories, 
milk and cheese, which are the two cases of this research, and which were chosen for the presence in them, of both types of brands; i.e. manufacturer brands and retailer house brands. The two categories were studied in two different supermarket chains of an umbrella retail organisation. The selection of the categories was also theory-driven (Miles \& Huberman, 1994) in the way it ensured the selection of information-rich cases (Patton, 1990; Saunders, Lewis \& Thornhill, 1997). Background information was established beforehand, of the level of activity of manufacturer and retailer house brands in the categories. Since the two categories were studied in two distinct supermarket chains, the research design is not really a classic case design as such. With classic case designs, there is no question about what the number of cases should be as the number is always a single case. Given that this research was set outside the classic case mode, the two categories studied enabled comparisons to be made. Conducting the classic case study is seen as conducting a single experiment, and conducting more than one case should be seen as conducting multiple experiments, and this facilitates the use of replication logic (Yin, 2003). In this study, the first dimension of literal and theoretical replication is the category, and the second dimension is the supermarket chain. Data collection was conducted using category observation and in-depth interviews, and the participating organisations and interview participants have been anonymised in this article as agreed with the participants at the time of data collection. The two categories and two supermarket chains studied, presented as cases and dimensions of literal and theoretical replication, are shown in Table 1.

Table 1. Categories and supermarket chains studied

\begin{tabular}{|c|c|}
\hline $\begin{array}{l}\text { Dimensions of literal and theoretical } \\
\text { replication }\end{array}$ & $\begin{array}{l}\text { Cases \& embedded } \\
\text { cases }\end{array}$ \\
\hline Dimension 1: Category & $\begin{array}{l}\text { Milk category } \\
\text { Cheese category }\end{array}$ \\
\hline Dimension 2: Supermarket chain & 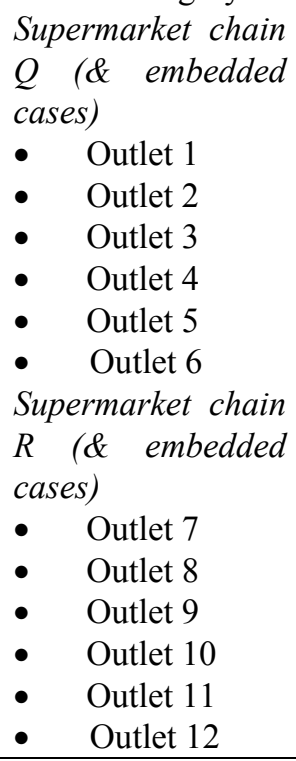 \\
\hline
\end{tabular}

Source: Compiled from in-store category observation and research interviews

Category observation exercises were conducted in each of the two categories in six outlets of supermarket chain $\mathrm{Q}$, and in each of the two categories in six outlets of supermarket chain R. The category observation study involved establishing shelf space for manufacturer and retailer house brands. Shelf space was established through measurement, using a tape measure, and this enabled the expression of the results in metres. While shelf space can be expressed in units of measurement of width such as centimetres or metres, it can also be expressed as the number of facings for each brand, and in this regard the shelf facings were established through counting. The width of shelf space occupied and the facings enjoyed are both triangulating measures of the same thing; i.e. shelf space. This observation study goes beyond restricted definitions of observation (e.g. Saunders et al., 1997; Ticehurst \& Veal, 2000) that seem to imply that such studies are all about observing people. The study takes the view that observation studies are broad in nature and can be applied to a wide variety of phenomena (Cooper \& Schindler, 2001). Cooper and Schindler (2001) divide observations into two broad types; behavioural observation, which involves observing persons; and nonbehavioural observation, which involves observing 
phenomenon like physical situations, records and processes. The observation study for this paper fits into the classification of nonbehavioural observation since it examines manufacturer and retailer brand physical, supermarket category situations related to shelf space.

In-depth interviews were undertaken with managers in each outlet where the category observation was conducted, and in addition, one of the interviews was carried out at the head office of the umbrella retail chain QR. In total 13 in-depth interviews were held face-to-face. The in-depth interview technique was chosen for this research as interviews have the capacity to facilitate digging into and understanding the reasons for the decisions taken (Saunders et al., 1997). The research used the semi-structured process of in-depth interviewing as it allows prior theory to be accommodated.

The idea of triangulating interview data with category observation data is therefore important as it enables testing for convergence (Parkhe, 1993). To further ensure the avoidance of interview bias, the researcher did not impose own reference frame on the interview participants, both when asking the questions and when interpreting them (Easterby-Smith, Thorpe \& Lowe, 1991). In addition, the triangulation of interview data with category observation data ensured that informant bias would be detected. The data analysis framework used consisted of three components; data reduction, data display, and conclusion drawing and verification (Miles \& Huberman, 1994). The three components were treated as interwoven in the entire research process (Miles \& Huberman, 1994). Category observation data was largely quantitative in nature and in-depth interview data collected was largely qualitative in nature. From the category observation data, simple means of shelf space occupied were determined across the categories and outlets studied. The research interview data was coded using thematic coding (Gibbs, 2007; Krippendorff, 2004). Replication logic was employed in cross-case comparisons, and quotes from interviews were used to support theoretical points.

The methodological limitation of this study is that the number of outlets covered with respect to category observation was not large enough to allow for more advanced statistical analysis techniques to be employed. This shortcoming however, is addressed by the use of complementary qualitative data from in-depth interviews. The triangulation of qualitative and quantitative data addresses the potential limitation that would otherwise be associated with a small sample. In addition, important to note is the fact that the research meant to make use of replication logic rather than statistical logic in drawing conclusions.

\section{Results and Discussion}

\subsection{Brief Description of the Categories in Question}

An initial quick run through the two categories (milk and cheese) incorporated in the study is necessary from the view-point that these categories are the units of analysis. The broader milk category within the supermarkets is grouped into a number categories and aisles such as standard milk, cream, flavoured milk and long-life milk. This study focused on standard milk. The standard milk category is a fairly commoditised category, and while retailer house brands would generally be more profitable to retailers than manufacturer brands, margins in this category have largely been eroded by the competitive activity between the grocery retail chains. Also, as far as the actual management of this category is concerned, both the retailers and the manufacturers have an input, via the category management operational practice. The other category, cheese, can be divided into standard cheese, specialty cheese and cultured products; and this study focused on standard cheese. Products that can be found in standard cheese include block cheese, grated cheese and sliced cheese. From the view-point of commoditisation of the category, it depends on the segment; for instance, standard cheese tends to be more inclined towards commoditisation. The segment is also generally price-driven, with whatever is on promotion tending to sell more. Again in the management of this category, there is input from both retailers and manufacturers through the operational practice of category management.

\subsection{Category Observation Study}

Results of the category observation exercise that was carried out are shown in Tables 2 and 3. These tables show mean data for the shelf space and shelf facings of retailer house brands and manufacturer brands in the two categories. The tables are based on condensed data compiled from more detailed tables that were prepared from the in-store category observation data collected. Since the study employed replication logic, comparisons made between manufacturer brands and retailer house brands in the categories and supermarkets largely sought literal and theoretical replication.

\subsubsection{Shelf Space in the Milk Category}

Shelf data for the milk category is furnished in Table 2 . 
Table 2. Shelf data, milk category

\begin{tabular}{llll}
\hline Shelf data & Type of brand & $\begin{array}{l}\text { Supermarket chain } Q \\
(n=6 \text { stores })\end{array}$ & $\begin{array}{l}\text { Supermarket chain } R \\
(n=6 \text { stores })\end{array}$ \\
\hline Mean shelf space & Retailer house brand & $4.74 \mathrm{~m} *(37.7 \%)$ & $8.46 \mathrm{~m}(31.8 \%)$ \\
& Manufacturer brand & $7.84 \mathrm{~m}(62.3 \%)$ & $18.17 \mathrm{~m}(68.2 \%)$ \\
Mean shelf facings & Retailer house brand & $39(32.5 \%)$ & $73.8(33.3 \%)$ \\
& Manufacturer brand & $81(67.5 \%)$ & $147.5(66.7 \%)$ \\
\hline
\end{tabular}

Source: Compiled from in-store category observation data $\left({ }^{*} \mathrm{~m}=\right.$ metres; e.g. $\left.4.74 \mathrm{~m}\right)$

Retailer house brand share for the milk category for the grocery retail chain (QR) studied was established through research interview and documentation supplied, and it stood at $52.6 \%$. While retailer house brand share would differ slightly from store to store and between supermarket chains/groups, this figure is taken as an initial estimate of the retailer house brand shares for supermarket group Q and supermarket group R, which both belong to the grocery retail chain $\mathrm{QR}$. With regard to shelf data, as can be seen in the table; mean shelf space and mean shelf facings are higher for manufacturer brands than retailer house brands in both supermarket groups $\mathrm{Q}$ and $\mathrm{R}$. In both supermarket groups, with respect to whether the retailer house brand is favoured on shelf matters; if the $52.6 \%$ share is taken as an indicator of the fair proportion of shelf allocation for retailer house brand, it means that the retailer house brand actually has slightly lower than expected shelf space and facings.

\subsubsection{Shelf Space in the Cheese Category}

Shelf data for the cheese category is given in Table 3. The retailer house brand share within the cheese category in grocery retail chain QR was established through research interview and documentation supplied as $30.8 \%$. This figure is taken to be an estimate of the retailer house brand shares of supermarket group Q and supermarket group R, that are under grocery retail chain QR. As can be seen in the table; mean shelf space and mean shelf facings are lower for retailer house brands than manufacturer brands in both supermarket groups. In relation to the stated category share, retailer house brands actually have lower mean shelf space and facings than would be expected.

With respect to these results therefore, it becomes difficult for one to take the view that the studied supermarket chains are giving preferential treatment to their retailer house brands in relation to manufacturer brands in the allocation of shelf space. Despite the fact that the setting of this study is a highly concentrated consumer packaged goods retail environment, decisions on shelf space do not seem to reflect the sheer use of power by the grocery retail chains concerned; a situation that would be reasonable to expect in a highly concentrated grocery retail environment. To shed more light on these issues, the research boasts qualitative data from in-depth interviews.

Table 3. Shelf data, cheese category

\begin{tabular}{llll}
\hline Shelf data & Type of brand & $\begin{array}{l}\text { Supermarket chain } Q \\
(n=6 \text { stores })\end{array}$ & $\begin{array}{l}\text { Supermarket chain } R \\
(n=6 \text { stores })\end{array}$ \\
\hline Mean shelf space & Retailer house brand & $2.41 \mathrm{~m}(21.1 \%)$ & $4.31 \mathrm{~m}(25.7 \%)$ \\
& Manufacturer brand & $8.98 \mathrm{~m}(78.9 \%)$ & $12.45 \mathrm{~m}(74.3 \%)$ \\
Mean shelf facings & Retailer house brand & $26(21.9 \%)$ & $49(22.2 \%)$ \\
& Manufacturer brand & $92.5(78.1 \%)$ & $171.7(77.8 \%)$ \\
\hline
\end{tabular}

Source: Compiled from in-store category observation data 


\subsection{In-depth Interviews}

A number of themes emerged with respect to decisions on the shelf space of manufacturer and retailer house brands in the categories studied. The first is that of category turnover. Superior category sales performance is achievable with the appropriate combination of manufacturer and retailer house brands and not with an overemphasis on any one of the two. "But if we are getting more private label and less turnover, I am not so happy" (Interview R4).

"If you had a chain store that was $100 \%$ private label and you have got another chain that was $50 / 50$, you would probably find the sales would go from the private label over [to the other store] ... I think at the end of the day, a good split would be like 60/40 ... overall" (Interview Q4).

The second theme is that of category profitability. If the retailer house brand would get disproportionately huge shelf space, this is perceived to have a negative impact on category profitability:

"Obviously you would sell more of the retailer brand but that affects your profitability... we have got to relay the shelf for profitability as well, and yes you have got your proprietary brand here, taking that part of the shelf, but we have also got the house brand taking up the other half of the shelf beside it ...” (Interview Q1).

The third theme is that of contract supply. The manufacturer brand also supplies retailer house brand. The retail chains get into agreements with manufacturers of manufacturer brands to supply retailer house brands for the retailers. "They [manufacturers] also supply house brand ... so they are getting two bites of it" (Interview Q1). Manufacturers therefore benefit from marketing the manufacturer brand that competes with the retailer house brand, and from contract supply of the retailer house brand. Logically, if the manufacturers could not be there to supply their own manufacturer brands, then they equally would not be there to supply the retailer house brand. In this regard, survival of the retailer house brand is dependent on the survival of the manufacturer brand.

Even if the two types of brands are in some form of competition, they are both equally important to the retailers. "There would always need to be a balance between private label and proprietor brands..." (Interview QR2). In addition, there is an understanding among the participants.

“I think there would be that understanding ... [that] we don't want to kill their product. We want to sit beside them and have a healthy share. We don't want them to dominate us and we don't want to dominate them because the category is driven by their strong products" (Interview R5a).

In combination, the themes of category turnover, category profitability and category supply are all largely category performance issues, and they are perceived not to be achievable with an overemphasis on retailer house brands at the expense of manufacturer brands. The dependence of the retailer house brand on the manufacturer brand and the dependence of the grocery retail chains on the manufacturer brand as a strategic resource are both adequate justification for shelf space allocation not to reflect power imbalances between manufacturers and retailers in the consumer packaged goods marketing environment of high grocery retail concentration. The findings of the category observation study are therefore consistent with the findings of the in-depth inverviews which act as an explanation (and triangulation) to what is going on in the categories.

\section{Conclusion}

Theoretically, the research has put a fresh perspective to the whole subject of shelf space allocation between manufacturer and retailer house brands by way of analysing the subject in a new environment, i.e. in a highly concentrated consumer packaged goods environment where grocery retailer strategic decisions would be expected to take advantage of the power imbalance between the grocery retailers and manufacturers. Previous research has generally been set in different contextual environments. This research has negated the possibility of power imbalances playing a significant role in the allocation of shelf space. Indeed, the research has highlighted dependency relationships between manufacturer brands and retailer house brands. Practically, the justification of treatment of shelf space between manufacturer and retailer house brands in the fashion unveiled in this research acts as a hint to grocery retailers in environments that are consolidating; that, despite the higher margins that may be commanded by retailer house brands over manufacturer brands, it makes more economic sense not to marginalise manufacturer brands. Merchandising policies that do not marginalise manufacturer brands reign supreme over those that do, especially from an overall category performance perspective. Future research could extent this investigation into more consumer packaged goods categories as this study was based on only two categories, and comparisons could also be made between commoditised and non-commoditised categories, as well as between consumer packaged goods environments that are highly concentrated and those that have a low level of consolidation and concentration. 


\section{References}

Amrouche, N., \& Zaccour, G. (2006). Shelf space allocation of national and private brands. European Journal of Operations Research, 180(2), 648-663. http://dx.doi.org/10.1016/j.ejor.2006.05.008

Bell, J. D., \& Duder, J. N. (1998, November). The battle for shelf-space in New Zealand supermarkets: Do supermarkets favour their own brands with extra and better positioned facings? Paper presented at the ANZMAC Conference, Dunedin, New Zealand.

Cooper, D. R., \& Schindler, P. S. (2001). Business research methods (7th ed.). New York, NY: McGraw-Hill/ Irwin.

Dreze, X., Hoch. S. J., \& Purk, M. E. (1994). Shelf management and space elasticity. Journal of Retailing, 70(4), 301-326. http://dx.doi.org/10.1016/0022-4359(94)90002-7

Easterby-Smith, M., Thorpe, R., \& Lowe, A. (1991). Management research: An introduction. London: Sage Publications.

Emerson, R. (1962). Power - dependence relations. American Sociological Review, 27(2), 31-41. http://dx.doi.org/10.2307/2089716

Frank, R. E., \& Massy, W. F. (1970). Shelf position and space effects on sales. Journal Marketing Research, 7(1), 59-66. http://dx.doi.org/10.2307/3149508

Gibbs, G. R. (2007). Analyzing qualitative data. London: Sage Publications.

Gomez, M., \& Rubio, N. (2008). Shelf management of store brands: Analysis of manufacturers' perceptions. International Journal of Retail and Distribution Management, 36(1), 50-70.

Guba, E. G., \& Lincoln, Y. S. (1994). Competing paradigms in qualitative research. In N. K. Denzin \& Y. S. Lincoln (Eds.), Handbook of qualitative research (105-117). Thousand Oaks, CA: Sage Publications.

Hickson, D. J., Hinings, C. R, Less, C. A., Schneck, R. E., \& Pennings, J. M. (1971). A strategic contingencies theory of organisational power. Administrative Science Quarterly, 16(2), 216-229. http://dx.doi.org/10.2307/2391831

Hoch, S. J. (1996). How should national brands think about private labels? International Journal of Retail and Distribution Management, 33(11), 858-878.

Hogarth-Scott, S. (1999). Retailer-supplier partnerships: Hostages to fortune or the way forward for the millennium? British Food Journal, 101(9), 668-682. http://dx.doi.org/10.1108/00070709910288865

Hultman, M., Opoku, R. A., Salehi-Shangari, E., Oghazi, P., \& Bui, Q. T. (2008). Private label competition: The perspective of Swedish branded goods manufacturers. Management Research News, 31(2), 125-141. http://dx.doi.org/10.1108/01409170810846849

Krippendorff, K. (2004). Content analysis: An introduction to its methods. Thousand Oaks, CA: Sage Publications.

Kumar, N., \& Steenkamp, J. E. M. (2007). Private label strategy: How to meet the store brand challenge. Boston, MA: Harvard Business School Press.

Miles, M. B., \& Huberman, A. M. (1994). Qualitative data analysis: An expanded sourcebook. Thousand Oaks, CA: Sage Publications.

Nielsen. (1992). Category management: Positioning your organisation to win. Chicago, IL: NTC Business Books.

Ogbonna, E., \& Wilkinson, B. (1998). Power relations in the UK grocery supply chain: Developments in the 1990s. Journal of Retailing and Consumer Services, 5(2), 77-86. http://dx.doi.org/10.1016/S0969-6989(97)00004-0

Parkhe, A. (1993). Messy research, methodological predispositions and theory development in international joint ventures. The Academy of Management Review, 18(2), 227-268.

Patton, M. Q. (1990). Qualitative evaluation and research methods. Newbury Park, CA: Sage Publications.

Perry, C., Riege, A., \& Brown. L, (1999). Realism's role amongst scientific paradigms in marketing research. Irish Marketing Review, 12(2), 16-23.

Pfeffer, J. (1981). Power in organisations. Marshfield: M. A. Pitman. 
Saunders, M., Lewis, P., \& Thornhill, A. (1997). Research methods for business students. London: Pitman Publishing.

Sethuraman, R. (2006). Private-label marketing strategies in packaged goods: Management beliefs and research insights (Research Report No. 06-108). Cambridge, MA: Marketing Science Institute.

Suárez, M. (2005). Shelf space assigned to store and national brands: A neural networks analysis. International Journal of Retail and Distribution Management, 33(11/12), 858-879.

Ticehurst, G. W., \& Veal, A. J. (2000). Business research methods: A managerial approach. Frenchs Forest, NSW: Longman.

Thompson, J. D. (1967). Organizations in action. New York, NY: McGraw-Hill Book Company.

Yin, R. K. (2003). Case study research: Design and methods. (3rd ed.). Thousand Oaks, CA: Sage Publications. 